\title{
Mesorhizobium thiogangeticum sp. nov., a novel sulfur-oxidizing chemolithoautotroph from rhizosphere soil of an Indian tropical leguminous plant
}

Correspondence

Wriddhiman Ghosh

Wriman@rediffmail.com
Wriddhiman Ghosh and Pradosh Roy

Department of Microbiology, Bose Institute, P-1/12, CIT Scheme VII-M, Kolkata - 700 054, India

The bacterial strain $\mathrm{SJT}^{\top}$, along with 15 other mesophilic, neutrophilic and facultatively sulfur-oxidizing chemolithotrophic isolates, was isolated by enrichment on reduced sulfur compounds as the sole energy and electron source from soils immediately adjacent to the roots of Clitoria ternatea, a slender leguminous herb of the Lower Gangetic plains of India. Strain SJT ${ }^{\top}$ was able to oxidize thiosulfate and elemental sulfur for chemolithoautotrophic growth. 16S rRNA and $\operatorname{rec} A$ gene sequence-based phylogenetic analyses showed that the Gram-negative rod-shaped bacterium belonged to the genus Mesorhizobium and was most closely related to Mesorhizobium loti, Mesorhizobium plurifarium, Mesorhizobium amorphae and Mesorhizobium chacoense. Unequivocally low $16 \mathrm{~S}$ rRNA $(<97 \%)$ and recA $(\leqslant 88 \%)$ gene sequence similarities to all existing species of the most closely related genera, a unique fatty acid profile, a distinct $\mathrm{G}+\mathrm{C}$ content $(59.6 \mathrm{~mol} \%)$ and phenotypic characteristics all suggested that strain $\mathrm{SJT}^{\top}$ represents a novel species. DNA-DNA hybridization and SDS-PAGE analysis of whole-cell proteins also confirmed the taxonomic uniqueness of $\mathrm{SJT}^{\top}$. It is therefore proposed that isolate $\mathrm{SJT}^{\top}$ $\left(=\right.$ LMG $22697^{\top}=$ MTCC $\left.7001^{\top}\right)$ be classified as the type strain of a novel species,

Mesorhizobium thiogangeticum sp. nov.
Taxonomy of the family Rhizobiaceae has undergone extensive revision in the last couple of decades and the description of a bacterium as a member of the family usually includes its ability to nodulate a leguminous host. However, it has also been found that symbiotic properties in some rhizobia are genetically unstable and the possibility of nonsymbiotic rhizobia (Segovia et al., 1991; Rogel et al., 2001) existing as significant components of rhizobial populations in the soil has been indicated (Sullivan et al., 1996).

From soil adjacent to the root of Clitoria ternatea, a slender leguminous herb (family Papilionaceae) that occurs on almost every piece of waste ground and in village forests of the Lower Gangetic plains of India, the mesophilic, neutrophilic, facultatively sulfur-oxidizing chemolithotrophic

Published online ahead of print on 9 September 2005 as DOI 10.1099/ijs.0.63967-0.

The GenBank/EMBL/DDBJ accession numbers for the 16S rRNA and $\operatorname{rec} A$ gene sequences of the strain $\mathrm{SJT}^{\top}$ are AJ864462 and AM040610, respectively.

Fatty acid profiles, a phenogram derived from UPGMA/S $S_{S M}$ analysis and SDS-PAGE analysis of whole-cell proteins of strain $\mathrm{SJT}^{\top}$ and related species are available as supplementary material in IJSEM Online. bacterial strain $\mathrm{SJT}^{\mathrm{T}}$ was isolated by enrichment, along with 15 other sulfur-oxidizing strains, on reduced sulfur compounds as the sole energy and electron source. Numerous plants were uprooted from a single plot of land and soil that adhered loosely to the roots was dislodged by gently striking the roots with sterile forceps. The collected pool of loose soil that was devoid of any root nodules was supplemented with $\mathrm{Na}_{2} \mathrm{~S}_{2} \mathrm{O}_{3} \cdot 5 \mathrm{H}_{2} \mathrm{O}(5 \%), \mathrm{Na}_{2} \mathrm{~S}(1 \%)$ and elemental sulfur powder $(5 \%)$ and incubated at $30^{\circ} \mathrm{C}$ for 2 weeks with intermittent sprinkling of sterile water. Enriched soil samples were added $(1 \%, \mathrm{w} / \mathrm{v})$ to MS-thiosulfate-yeast extract (MSTY; $20 \mathrm{mM} \mathrm{Na} \mathrm{S}_{2} \mathrm{O}_{3} .5 \mathrm{H}_{2} \mathrm{O}$ supplemented with $5.0 \mathrm{~g}$ yeast extract $\mathrm{l}^{-1}$ ) liquid medium $(\mathrm{pH} \mathrm{7 \cdot 0-7 \cdot 5)}$ based on a modified basal and mineral salts (MS) solution that contained the following $\left(\mathrm{l}^{-1}\right.$ distilled water): $1 \mathrm{~g} \mathrm{NH}_{4} \mathrm{Cl}, 4 \mathrm{~g}$ $\mathrm{K}_{2} \mathrm{HPO}_{4}, 1.5 \mathrm{~g} \mathrm{KH}_{2} \mathrm{PO}_{4}, 0.5 \mathrm{~g} \mathrm{MgSO}_{4} .7 \mathrm{H}_{2} \mathrm{O}$ and $5.0 \mathrm{ml}$ trace metals solution (Vishniac \& Santer, 1957). Mixtures were incubated at $30^{\circ} \mathrm{C}$ on a rotary shaker until the colour of the phenol red indicator added to the medium changed to yellow. Serial dilutions from the soil-MSTY broth mixture were plated on MSTY agar and incubated at $30^{\circ} \mathrm{C}$. Strain $\mathrm{SJT}^{\mathrm{T}}$, which could be distinguished in terms of colony morphology and the rate and extent of acid production in chemolithoautotrophic MS-thiosulfate (MST; $20 \mathrm{mM}$ $\mathrm{Na}_{2} \mathrm{~S}_{2} \mathrm{O}_{3} \cdot 5 \mathrm{H}_{2} \mathrm{O}$ plus $50 \mathrm{mg}$ yeast extract $\mathrm{l}^{-1}$ as growth factor 
supplement) and mixotrophic MSTY media, was isolated as a pure culture.

All growth experiments were performed at $30^{\circ} \mathrm{C}$ and yeast extract $\left(50 \mathrm{mg} \mathrm{l}^{-1}\right)$ or a vitamin mixture $(10 \mathrm{mg}$ each of nicotinic acid, pantothenic acid, pyridoxine, thiamin, $p$ aminobenzoic acid, riboflavin and biotin $1^{-1}$ ) was always added to the medium. Cells were tested for their ability to use thiosulfate $(12-20 \mathrm{mM})$, sulfide $(2 \mathrm{mM})$, sulfite $(3 \mathrm{mM})$, thiocyanate $(2$ or $5 \mathrm{mM})$, elemental sulfur $(0.5$ and $1.0 \%$, $\mathrm{w} / \mathrm{v})$ or tetrathionate $(10 \mathrm{mM})$ as a substrate for chemolithotrophic growth. For testing mixotrophic utilization of sulfur compounds, yeast extract $\left(2 \cdot 5\right.$ or $\left.5 \cdot 0 \mathrm{~g} \mathrm{l}^{-1}\right)$ was added to the above formulations. The level of thiosulfate or tetrathionate in the medium was estimated by the cyanolytic method described by Kelly \& Wood (1994). Strain SJT ${ }^{\mathrm{T}}$ was facultatively chemolithotrophic and could grow on 12$20 \mathrm{mM}$ thiosulfate as the sole energy and electron source, but not on soluble sulfide, thiocyanate, tetrathionate or sulfite under the experimental conditions used. It also utilized elemental sulfur $\left(10 \mathrm{~g} \mathrm{l}^{-1}\right)$ for chemolithotrophic growth, with a corresponding increase in the $\mathrm{OD}_{600}$ of the broth cultures by an order of $0 \cdot 2$, which is attributable to oxidation and the disappearance of colloidal sulfur, along with lowering of the $\mathrm{pH}$ of the medium from $7 \cdot 5$ to $6 \cdot 2$ over an incubation period of 5 days. Details of chemolithotrophic growth and thiosulfate consumption by $\mathrm{SJT}^{\mathrm{T}}$ in MST or MSTY medium containing $20 \mathrm{mM}$ sodium thiosulfate, equivalent to $40 \mu \mathrm{g}$ sulfur atoms $\mathrm{ml}^{-1}$, are shown in Table 1.

All other phenotypic tests were performed using standard techniques described elsewhere (Gerhardt et al., 1994). The bacterium could grow in complex media like LuriaBertani (LB) broth, nutrient broth (NB) and MS-peptone casein hydrolysate. Poor growth was observed on yeast

Table 1. Utilization of thiosulfate and concomitant decrease in $\mathrm{pH}$ of the medium over 4 days of growth by the novel strain $\mathrm{SJT}^{\top}$ in chemolithotrophic medium at $30^{\circ} \mathrm{C}$

The initial concentration of thiosulfate $\left(\mathrm{Na}_{2} \mathrm{~S}_{2} \mathrm{O}_{3}\right)$ in both media was $20 \mathrm{mM}$ (equivalent to $40 \mu \mathrm{g}$ sulfur atoms $\mathrm{ml}^{-1}$ ). The increase in $\mathrm{OD}_{600}$ is attributed to thiosulfate utilization and values presented were calculated after eliminating background growth of the bacteria in basal salts medium without thiosulfate. The initial $\mathrm{pH}$ of thiosulfate-containing media was $7 \cdot 5$.

\begin{tabular}{|lcc|}
\hline Parameter & MST & MSTY \\
\hline $\begin{array}{l}\text { Thiosulfate consumption } \\
\text { after incubation for: }\end{array}$ & \\
1 day & 8 & 12 \\
2 days & 12 & 20 \\
3 days & 24 & 28 \\
4 days & 30 & 34 \\
Final OD 600 & $0 \cdot 10-0 \cdot 15$ & - \\
Final pH of spent medium & $5 \cdot 5$ & $5 \cdot 8$ \\
\hline
\end{tabular}

extract-mannitol agar (YMA). In synthetic heterotrophic media, i.e. MS solution plus one organic carbon source $\left(5 \mathrm{~g} \mathrm{l}^{-1}\right)$ supplemented with vitamin mixture, the isolate could utilize only a few carbon compounds.

The 16S rRNA gene was amplified and its sequence was determined from PCR products using universal primers (Gerhardt et al., 1994). Evolutionary distances were calculated by pairwise comparison of the aligned $16 \mathrm{~S}$ rRNA gene sequences (Jukes \& Cantor, 1969) by the program DNADIST. A consensus neighbour-joining tree (Saitou \& Nei, 1987) was constructed following majority rule and strict consensus out of 100 phylogenetic trees produced using the program NEIGHBOR in PHYLIP version 3.572c (Felsenstein, 1993). Bootstrap values (100 replicates) were calculated by the method of Felsenstein (1985) to validate the reproducibility of the branching pattern of the tree. 16S rRNA gene sequence-based phylogenetic analysis of $\mathrm{SJT}^{\mathrm{T}}$ showed that the strain had maximum $16 \mathrm{~S}$ rRNA gene sequence similarity $(96 \cdot 2-96 \cdot 8 \%)$ to species of Mesorhizobium, e.g. Mesorhizobium loti, Mesorhizobium plurifarium, Mesorhizobium amorphae and Mesorhizobium chacoense, and occupied the same phylogenetic branch as Mesorhizobium species (Fig. 1). Species of other genera, i.e. Sinorhizobium fredii ( $96 \%$ ), Aminobacter aminovorans (95.7\%), Aminobacter aganoensis (95.6\%) and Aminobacter niigataensis (95.6\%), had still lower $16 \mathrm{~S}$ rRNA gene sequence similarity to $\mathrm{SJT}^{\mathrm{T}}$, whereas strains of Pseudaminobacter salicylatoxidans exhibited $\leqslant 94 \%$ rRNA gene sequence similarity to $\mathrm{SJT}^{\mathrm{T}}$. Strain KCT001, a thiosulfate- and tetrathionate-oxidizing facultatively chemolithotrophic member of Pseudaminobacter salicylatoxidans (Deb et al., 2004) exhibited 94\% 16S rRNA gene sequence similarity to $\mathrm{SJT}^{\mathrm{T}}$. A Mexican soil isolate, designated Ls29 and identified as a strain of M. plurifarium, showed slightly higher $16 \mathrm{~S}$ rRNA gene sequence similarity $(97 \cdot 1 \%)$ to $\mathrm{SJT}^{\mathrm{T}}$.

Phylogeny of the recA gene (encoding part of the DNA recombination and repair system) in rhizobial taxa (Gaunt et al., 2001; Weir et al., 2004; Vinuesa et al., 2005) has been shown to be congruent with that of the small-subunit rRNA genes with well-supported clades for members of Mesorhizobium species having unequivocal bootstrap supports (Gaunt et al., 2001). Moreover, large-scale phylogenies of $r e c A$ in the Bacteria as a whole have been found to be consistent with the corresponding rRNA gene sequence-based phylogenies (Eisen, 1995; Young, 1998).

A recA gene fragment was amplified by PCR from isolate SJT $^{\mathrm{T}}$ using published recA primers (Gaunt et al., 2001) [recA 6 (forward; CGKCTSGTAGAGGAYAAATCGGTGGA) and recA 555 (reverse; CGRATCTGGTTGATGAAGATCACCAT), where mixtures of bases used at certain positions are as follows: K, T or G; S, G or C; Y, C or T; R, A or G]. The recA gene sequence-based phylogenetic affinities of strain $\mathrm{SJT}^{\mathrm{T}}$ were reconstructed using the neighbour-joining method (Saitou \& Nei, 1987) with distances estimated using JukesCantor as well as Kimura's two-parameter models with 100 bootstrap replications. 


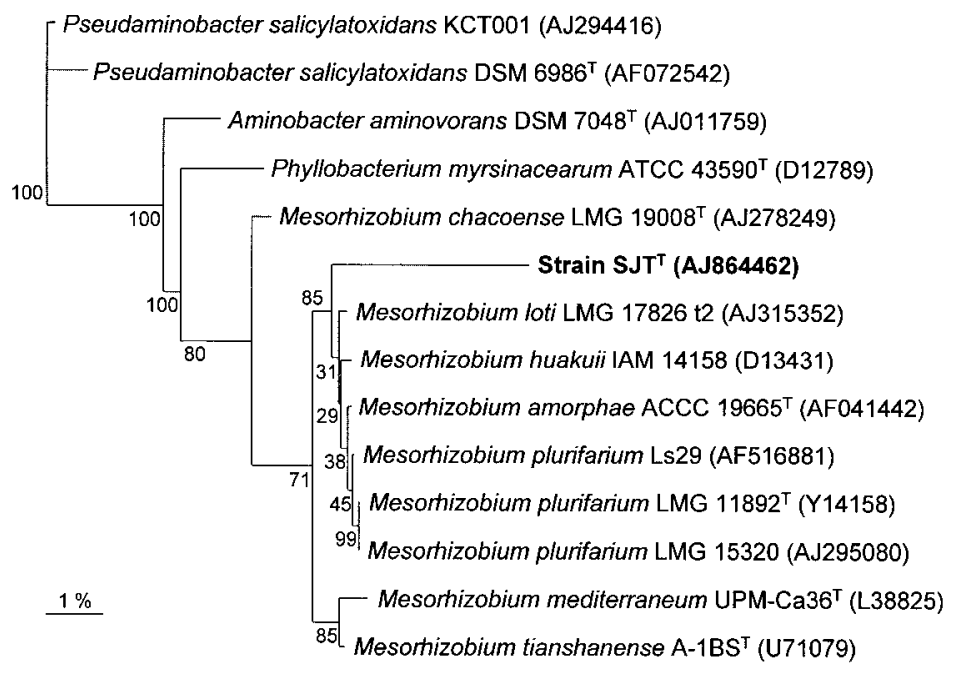

Fig. 1. Neighbour-joining tree of the novel isolate Mesorhizobium thiogangeticum $\mathrm{SJT}^{\top}$ and phylogenetically related bacteria constructed on the basis of their 16S rRNA gene sequences. Bar, 1\% nucleotide difference. GenBank accession numbers are given beside the strain numbers and bootstrap probability values (based on 100 replications) are indicated at the major branch-points.
Phylogenetic analysis based on the recA gene sequence also placed $\mathrm{SJT}^{\mathrm{T}}$ in the same evolutionary branch as Mesorhizobium species (Fig. 2). The partial recA gene sequence of strain SJT $^{\mathrm{T}}$ had maximum similarity $(88 \%)$ to strains of M. loti, whereas other rhizobial isolates awaiting specific designation and tentatively described as Mesorhizobium species (Weir et al., 2004) also exhibited $88 \%$ nucleotide sequence similarity to the $\operatorname{rec} A$ gene of $\mathrm{SJT}^{\mathrm{T}}$. The translated amino acid sequences of the recA genes of these organisms had $97 \%$ identity to that of $\mathrm{SJT}^{\mathrm{T}}$. The partial $\operatorname{rec} A$ gene sequences of strains of $M$. plurifarium, Mesorhizobium huakuii, Mesorhizobium tianshanense, Mesorhizobium ciceri, Mesorhizobium mediterraneum, M. amorphae and M. chacoense had $85-87 \%$ similarity to that of strain $\mathrm{SJT}^{\mathrm{T}}$. The translated amino acid sequences of the $\operatorname{rec} A$ genes of all these Mesorhizobium species had 96-97\% identity to that of $\mathrm{SJT}^{\mathrm{T}}$. $\operatorname{rec} A$ gene sequence similarities of the novel sulfuroxidizing chemolithotroph with species of other genera like
Rhizobium, Sinorhizobium, Agrobacterium, Azorhizobium, Bradyrhizobium, Rhodopseudomonas, Mycoplana and Brucella were much lower, between 80 and $84 \%$ (Fig. 2), whereas the translated amino acid sequences of the recA genes of these organisms had obviously lower identities $(<96 \%)$ to that of strain $\mathrm{SJT}^{\mathrm{T}}$.

High-molecular-mass DNA was prepared as described by Ezaki et al. (1988) with minor modifications. Dot-blot hybridization experiments were carried out with the DIG DNA Labelling and Detection system as described previously (Labrenz et al., 2000) to determine DNA-DNA binding values. The taxonomic uniqueness of $\mathrm{SJT}^{\mathrm{T}}$ was supported by its low DNA-DNA binding values with the four phylogenetically closest species: M. plurifarium LMG $11892^{\mathrm{T}}$ (28\%); M. loti LMG 17826 t2 (24\%); M. amorphae LMG 18932 (18\%); and M. chacoense LMG $19008^{\mathrm{T}}(22 \%)$. The phylogenetically related sulfur-oxidizing chemolithotrophic

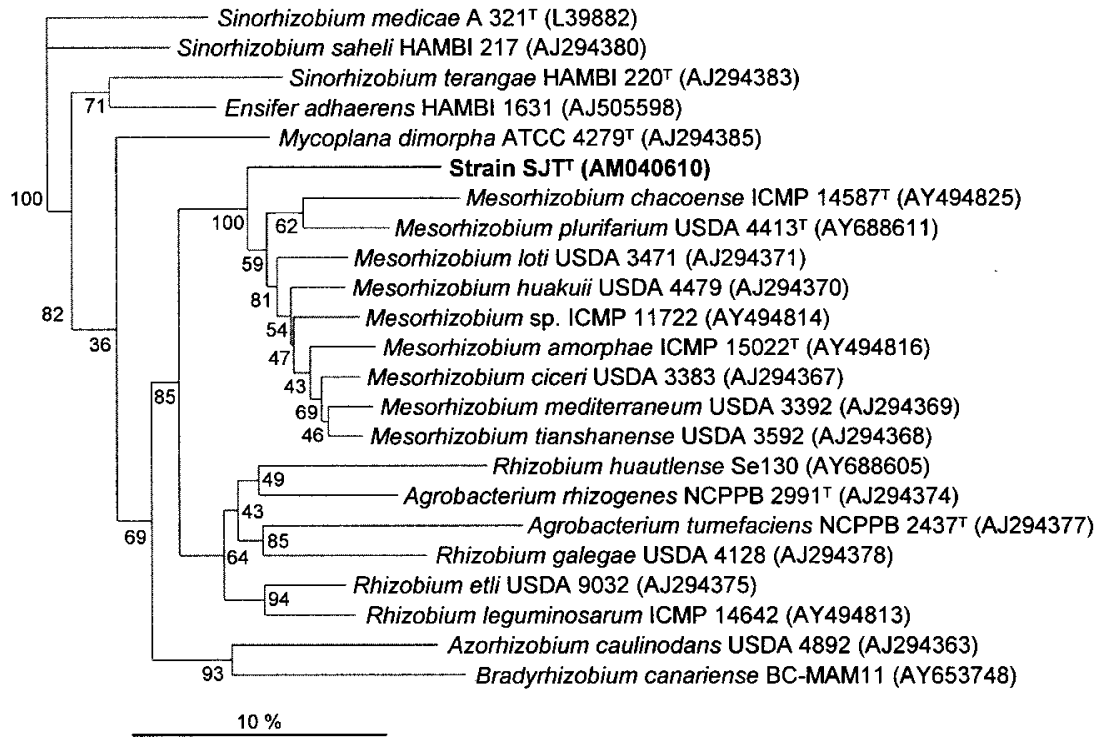

Fig. 2. Neighbour-joining tree of strain $S J T^{\top}$ and closely related bacteria constructed on the basis of their recA gene sequences. Bar, $10 \%$ nucleotide difference. GenBank accession numbers are given beside the strain numbers and bootstrap probability values (based on 100 replications) are indicated at the major branch-points. 
Pseudaminobacter salicylatoxidans KCT001 (Deb et al., 2004) exhibited an even lower DNA-DNA binding value $(10 \%)$ with $\mathrm{SJT}^{\mathrm{T}}$.

In this connection, it is noteworthy that homologues of the sulfur oxidation (Sox) genes discovered by virtue of genetic studies with alphaproteobacteria like Paracoccus pantotrophus, Pseudaminobacter salicylatoxidans strain KCT001 and Rhodovulum sulfidophilum (Friedrich et al., 2000; Mukhopadhyaya et al., 2000; Rother et al., 2001; AppiaAyme et al., 2001; C. Lahiri, S. Mandal, W. Ghosh, B. Dam and P. Roy, unpublished observations) have also been revealed from whole genome sequence analyses of several species of the order Rhizobiales (Kaneko et al., 2002; see NCBI Microbial Genomes Annotation Project, accession no. NZ_AAAF01000001 for Rhodopseudomonas palustris). However, despite the close phylogenetic relationship of the two organisms, no hybridization was detected, even under low stringency conditions, when the genomic DNA of $\mathrm{SJT}^{\mathrm{T}}$ was probed by Southern hybridization with DIG-labelled soxT, soxYZ or soxBC gene fragments from Pseudaminobacter salicylatoxidans KCT001 (Mukhopadhyaya et al., 2000; GenBank/EMBL accession number AJ404005) (data not shown). A distinct DNA G $+\mathrm{C}$ content of $59.6 \mathrm{~mol} \%$, determined using HPLC as described by Mesbah et al. (1989), was observed for $\mathrm{SJT}^{\mathrm{T}}$, which differs from the G $+\mathrm{C}$ contents of most of the closely related species of Mesorhizobium, thus reiterating the distinction of the isolate as a unique member of the mesorhizobia.

At the same time, the reference strains $M$. plurifarium LMG $11892^{\mathrm{T}}$, M. loti LMG 17826 t2, M. amorphae LMG 18932 and M. chacoense LMG $19008^{\mathrm{T}}$ were tested for their ability to oxidize or chemolithotrophically utilize thiosulfate in autotrophic MST or mixotrophic MSTY media. However, these mesorhizobial strains phylogenetically closest to $\mathrm{SJT}^{\mathrm{T}}$ could neither oxidize nor grow in MST or MSTY medium under the experimental conditions used.

Nodulating ability of $\mathrm{SJT}^{\mathrm{T}}$ was tested on Clitoria ternatea, as well as two other economically important leguminous plants (Pisum sativum and Cicer arietinum). Seeds were surfacesterilized in concentrated $\mathrm{H}_{2} \mathrm{SO}_{4}$ for $20 \mathrm{~min}$. After the acid was drained, seeds were washed thoroughly with 10 changes of sterile water and placed in moistened steam-sterilized sand to germinate at $28^{\circ} \mathrm{C}$ for $3-5$ days. Germinating seedlings, 3-4 cm long, were inoculated at the base of the stem or the radicle-plumule junction with $1 \mathrm{ml} \mathrm{SJT}^{\mathrm{T}}$ inoculum (heavy suspension of LB broth-grown exponentialphase culture in $10 \mathrm{ml}$ nitrogen-free Jensen solution, $\mathrm{pH}$ 6.8) and placed in a steam-sterilized sand-vermiculite mixture in $12 \mathrm{~cm}$ diameter pots and left to establish in the greenhouse at $28^{\circ} \mathrm{C}$. The surface was covered with polyurethane beads to prevent evaporation and contamination. Plants were watered with a sterile nitrogen-free nutrient solution once in 3 days. Saplings were checked for the presence of nodules after 10 weeks of growth. None of the plant species (10-15 individual saplings were taken for each plant species) inoculated with $\mathrm{SJT}^{\mathrm{T}}$ were found to develop nodules. Positive controls of Cicer arietinum seedlings inoculated with $M$. ciceri ATCC $51585^{\mathrm{T}}$ developed nodules, whereas uninoculated plants did not. Since the negative observations found in these cases cannot be taken as attributes of the organism, it cannot be confirmed that $\mathrm{SJT}^{\mathrm{T}}$ does not have the potential to nodulate any plant host.

The inability to utilize maltose, raffinose, L-alanine, rhamnose, fructose, L-arabinose, sucrose or lactose as single carbon sources, fast growth rates, growth in LB medium and chemolithotrophic utilization of thiosulfate and sulfur are some of the phenotypic characters that discriminate strain $\mathrm{SJT}^{\mathrm{T}}$ from its phylogenetic relatives. Numerical analysis of all the available comparative phenotypic characteristics was performed using the simple matching coefficient $\left(S_{\mathrm{SM}}\right)$ (Sneath \& Sokal, 1973) followed by generation of phenograms using the unweighted pair group with mathematical averages (UPGMA) algorithm. These analyses largely corroborated the phylogenetic and genetic distinctiveness of strain $\mathrm{SJT}^{\mathrm{T}}$. Table 2 shows the key phenotypic characters that distinguish $\mathrm{SJT}^{\mathrm{T}}$ from the most closely related Mesorhizobium species and Pseudaminobacter salicylatoxidans; the phenogram derived from UPGMA/ $S_{\mathrm{SM}}$ analysis of the phenetic characteristics of $\mathrm{SJT}^{\mathrm{T}}$ with respect to the nearest mesorhizobia is available as Supplementary Fig. S1 in IJSEM Online. Polyphasic evaluation that included almost $70 \%$ phenotypic similarity to standard strains of M. plurifarium (Wang et al., 2003) and high 16S rRNA gene sequence similarity $(98 \cdot 75 \%)$ to the type strain (LMG $\left.11892^{\mathrm{T}}\right)$ of the species identified Ls29 as a strain of $M$. plurifarium. However, $\mathrm{SJT}^{\mathrm{T}}$ had several phenotypic dissimilarities from Ls29 (Table 2) and a lower $S_{\text {SM }}$ value $(60 \%)$.

SDS-PAGE analysis of whole-cell proteins also yielded distinct profiles for $\mathrm{SJT}^{\mathrm{T}}$ when compared with Pseudaminobacter salicylatoxidans KCT001 or the four nearest mesorhizobia, M. plurifarium LMG $11892^{\mathrm{T}}$, M. loti LMG 17826 t2, M. amorphae LMG 18932 and M. chacoense LMG $19008^{\mathrm{T}}$ (Supplementary Fig. S2).

Cellular fatty acid profiles have also been shown to discern species of Mesorhizobium accurately and to distinguish between related genera (de Lajudie et al., 1998; Tighe et al., 2000). After an incubation period of $40 \mathrm{~h}$ at $30{ }^{\circ} \mathrm{C}$ on $\mathrm{LB}$ agar, a loopful of well-grown cells was harvested and the preparation, separation and identification of fatty acids were performed using the Sherlock Microbial Identification system (Microbial ID) at the DSMZ (Braunschweig, Germany). Strain $\mathrm{SJT}^{\mathrm{T}}$ synthesized 16:0, 17:0, 18:0, $17: 0$ iso, $17: 1 \omega 8 c, 18: 1 \omega 7 c$ and $19: 0$ cyclo $\omega 8 c$ fatty acids, thus confirming its classification as a species of Mesorhizobium. On the other hand, $\mathrm{SJT}^{\mathrm{T}}$ was distinct from all related mesorhizobia by its unique possession of $14: 0,18: 03-\mathrm{OH}, 15: 0$ iso $3-\mathrm{OH}$, relatively large amounts $(77 \cdot 41 \%)$ of $18: 1 \omega 7 c$, and the absence of $13: 0$ iso $3-\mathrm{OH}, 12: 03-\mathrm{OH}$ and $17: 0$ cyclo. The fatty acid profile also set $\mathrm{SJT}^{\mathrm{T}}$ apart from species of other phylogenetically related genera like Aminobacter, Pseudaminobacter and Sinorhizobium (Supplementary Table S1). 
Table 2. Phenotypic characteristics that are useful for differentiation of Mesorhizobium thiogangeticum $\mathrm{SJT}^{\top}$ from related taxa

Species:1, M. thiogangeticum sp. nov. SJT ${ }^{\mathrm{T}}$; 2, M. loti; 3, M. plurifarium Ls29 (a Mexican strain); 4, M. plurifarium (characters observed for standard strains); 5, M. amorphae; 6, M. chacoense; 7, M. mediterraneum; 8, M. huakuii; 9, Pseudaminobacter salicylatoxidans. +, Positive; -, negative; d, strain-dependent; NA, data not available. The table was adapted from Wang et al. (2003). Some other information was taken from de Lajudie et al. (1998), Wang et al. (1999), Velázquez et al. (2001), Kämpfer et al. (1999) and Deb et al. (2004).

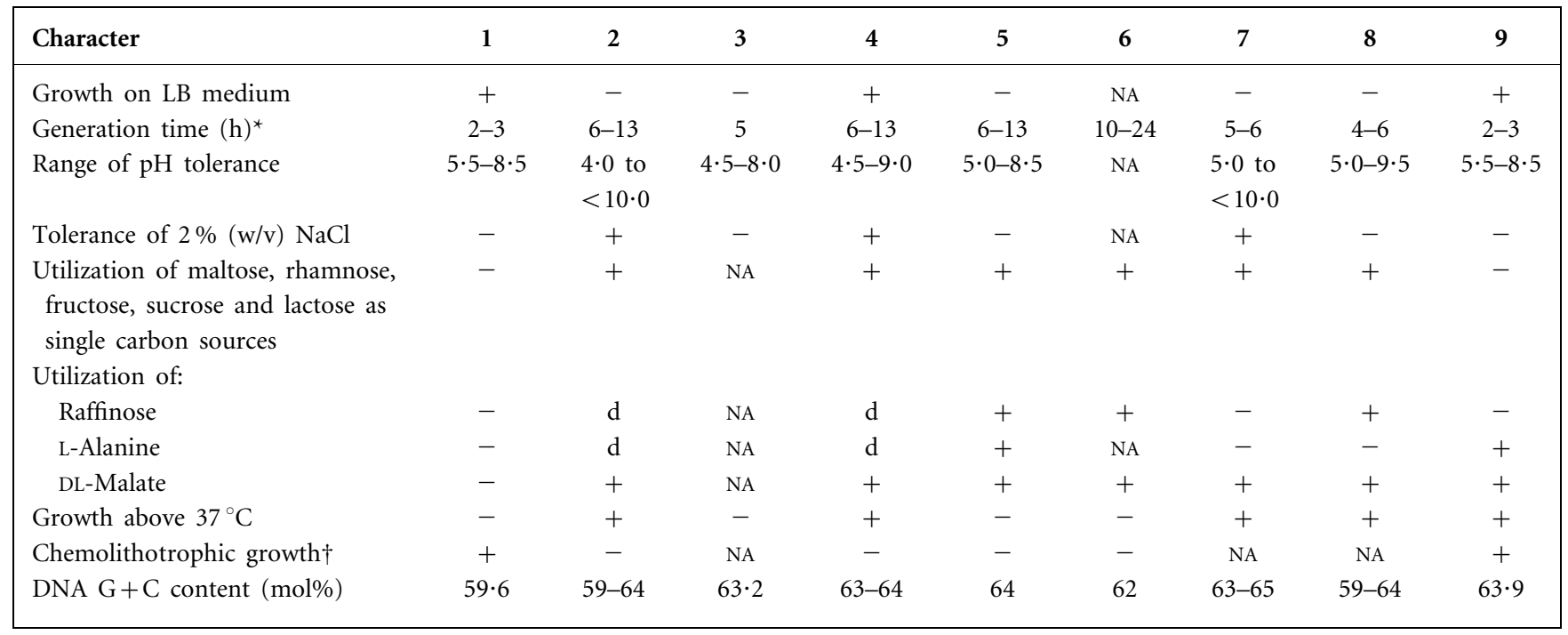

${ }^{\star}$ Generation time determined on LB medium for strain $\mathrm{SJT}^{\mathrm{T}}$ and Pseudaminobacter salicylatoxidans KCT001, YMA medium for M. chacoense and M. loti and PY medium for the remaining species.

$\dagger$ Chemolithotrophic oxidation of sulfur compounds was tested with the type strains of M. loti, M. plurifarium, M. amorphae and M. chacoense in the present study.

From the above findings, it is evident that the novel mesophilic, neutrophilic and facultatively sulfur-oxidizing chemolithoautotrophic isolate constitutes a unique taxonomic entity that belongs to the genus Mesorhizobium, but is distinct from all known species of the genus. Strain $\mathrm{SJT}^{\mathrm{T}}$ is thus classified as the type strain of a novel species, Mesorhizobium thiogangeticum sp. nov. However, in the absence of an adequate number of strains required to describe a bacterial species in general and a rhizobial species in particular, the complete description and delimitation of the novel species can only be finalized when more isolates are discovered or become available.

\section{Description of Mesorhizobium thiogangeticum sp. nov.}

Mesorhizobium thiogangeticum (thi.o.gan.ge'ti.cum. Gr. neut. n. thion sulfur; L. neut. adj. gangeticum from Ganga; N.L. neut. adj. thiogangeticum because the bacterium is so far the only sulfur-lithotrophic member of Mesorhizobium and is a native of the Gangetic plains of India).

Gram-negative, aerobic, non-spore-forming, irregularly elongated or rod-shaped bacterium (cells $1 \cdot 2-1 \cdot 5 \times 0 \cdot 2-$ $0.4 \mu \mathrm{m}$ ). Colonies on LB or MSTY media are shining white, convex, opaque and reach $1-3 \mathrm{~mm}$ in diameter within 4-5 days at $30^{\circ} \mathrm{C}$. Maximum temperature for growth is $37^{\circ} \mathrm{C}$ and range of $\mathrm{pH}$ tolerance is $5 \cdot 5-8 \cdot 5$. Catalasepositive, but oxidase-negative. Strain $\mathrm{SJT}^{\mathrm{T}}$ cannot liquefy gelatin, produce indole or solubilize phosphate. It can grow heterotrophically in complex media like LB, NB, YMA and MS-peptone casein hydrolysate. In synthetic media supplemented with $50 \mathrm{mg}$ yeast extract $\mathrm{l}^{-1}$ or vitamin mixture, the isolate utilizes only a few carbon compounds, D-glucose, L-arabinose, D-galactose, D-mannitol, L-histidine, L-leucine, L-isoleucine, L-glutamine, succinate and sodium benzoate, as the sole source of energy for chemo-organoheterotrophic growth. No growth is observed with citrate, oxalate, malate, acetate, maltose, sucrose, glycerol, myo-inositol, mandelate, DL-lactate, D-fructose, D-raffinose, D-xylose, D-lactose, L-aspartic acid, L-lysine, L-cysteine, L-cystine, L-tyrosine, L-threonine, L-alanine, L-serine, D-mannose, L-arginine or tryptophan. No growth is observed in nitrogen-free Burk medium under aerobic conditions. Chemolithoautotrophic growth is observed with thiosulfate and elemental sulfur, but not tetrathionate, thiocyanate, soluble sulfides, sulfite or arsenite. Synthesizes the following fatty acids: 14:0 $(0 \cdot 88 \%), 15: 0$ iso $(8 \cdot 23 \%)$, summed feature $3(16: 1 \omega 7 \mathrm{cl}$ $15: 0$ iso $2-\mathrm{OH})(1 \cdot 82 \%), 16: 0(2 \cdot 46 \%), 15: 0$ iso $3-\mathrm{OH}$ $(0 \cdot 41 \%), 17: 0$ iso $(0 \cdot 85 \%), 17: 1 \omega 8 c(0 \cdot 51 \%), 17: 0$ $(0 \cdot 81 \%), 18: 1 \omega 7 c(77 \cdot 41 \%), 18: 0(1 \cdot 28 \%), 11-$ methyl $18: 1 \omega 7 c(4 \cdot 23 \%), 19: 0$ cyclo $\omega 8 c(0 \cdot 64 \%)$ and $18: 03-\mathrm{OH}$ $(0 \cdot 47 \%)$. The DNA G $+\mathrm{C}$ content of the type strain is $59 \cdot 6 \mathrm{~mol} \%$, as determined by HPLC. 
The type strain, strain $\mathrm{SJT}^{\mathrm{T}}\left(=\mathrm{LMG} 22697^{\mathrm{T}}=\right.$ MTCC $7001^{\mathrm{T}}$ ), is the only known strain of the species, isolated from soil adjacent to the roots of the leguminous plant Clitoria ternatea, a native of the lower Gangetic plains of India.

\section{Acknowledgements}

This paper is only a small part of the wide perspectives and vision of Dr Pradosh Roy whose untimely demise begets his unfortunate student W. G. to see the publication through on his behalf. We thank the DSMZ, Germany for helping in the analysis of fatty acid contents of the new isolate and the BCCM/LMG bacteria collection, Universiteit Gent, for providing custom services regarding determination of $\mathrm{G}+\mathrm{C}$ content and DNA sequencing. W. G. was provided with a fellowship from a research project (no. 37/1091/02-EMR-II) of the Council of Scientific and Industrial Research (CSIR), India.

\section{References}

Appia-Ayme, C., Little, P. J., Matsumoto, Y., Leech, A. P. \& Berks, B. C. (2001). Cytochrome complex essential for photosynthetic oxidation of both thiosulfate and sulfide in Rhodovulum sulfidophilum. J Bacteriol 183, 6107-6118.

Deb, C., Stackebrandt, E., Pradella, S., Saha, A. \& Roy, P. (2004). Phylogenetically diverse new sulfur chemolithotrophs of alphaproteobacteria isolated from Indian soils. Curr Microbiol 48, $452-458$.

de Lajudie, P., Willems, A., Nick, G. \& 9 other authors (1998). Characterization of tropical tree rhizobia and description of Mesorhizobium plurifarium sp. nov. Int $J$ Syst Bacteriol 48, 369-382.

Eisen, J. A. (1995). The RecA protein as a model molecule for molecular systematic studies of bacteria: comparison of trees of RecAs and 16S rRNAs from the same species. J Mol Evol 41, 1105-1123.

Ezaki, T., Hashimoto, Y., Takeuchi, N., Yamamoto, H., Liu, S. L., Miura, H., Matsui, K. \& Yabuuchi, E. (1988). Simple genetic method to identify viridans group streptococci by colorimetric dot hybridization and fluorometric hybridization in microdilution wells. J Clin Microbiol 26, 1708-1713.

Felsenstein, J. (1985). Confidence limits on phylogenies: an approach using the bootstrap. Evolution 39, 783-791.

Felsenstein, J. (1993). PHYLIP (phylogenetic inference package), version 3.5c. Distributed by the author. Department of Genome Sciences, University of Washington, Seattle, USA.

Friedrich, C. G., Quentmeier, A., Bardischewsky, F., Rother, D., Kraft, R., Kostka, S. \& Prinz, H. (2000). Novel genes coding for lithotrophic sulfur oxidation of Paracoccus pantotrophus GB17. J Bacteriol 182, 4677-4687.

Gaunt, M. W., Turner, S. L., Rigottier-Gois, L., Lloyd-Macgilp, S. A. \& Young, J. P. (2001). Phylogenies of atpD and recA support the small subunit rRNA-based classification of rhizobia. Int $J$ Syst Evol Microbiol 51, 2037-2048.

Gerhardt, P., Murray, R. G. E., Wood, W. A. \& Krieg, N. R. (editors) (1994). Methods for General and Molecular Bacteriology. Washington, DC: American Society for Microbiology.

Jukes, T. H. \& Cantor, C. R. (1969). Evolution of protein molecules. In Mammalian Protein Metabolism, vol. 3, pp. 21-132. Edited by H. N. Munro. New York: Academic Press.

Kämpfer, P., Müller, C., Mau, M., Neef, A., Auling, G., Busse, H.-J., Osborn, A. M. \& Stolz, A. (1999). Description of Pseudaminobacter gen. nov. with two new species, Pseudaminobacter salicylatoxidans sp. nov. and Pseudaminobacter defluvii sp. nov. Int J Syst Bacteriol 49, 887-897.

Kaneko, T., Nakamura, Y., Sato, S. \& 14 other authors (2002). Complete genomic sequence of nitrogen-fixing symbiotic bacterium Bradyrhizobium japonicum USDA110. DNA Res 9, 189-197.

Kelly, D. P. \& Wood, A. P. (1994). Synthesis and determination of thiosulfate and polythionates. Methods Enzymol 243, 475-501.

Labrenz, M., Tindall, B. J., Lawson, P. A., Collins, M. D., Schumann, P. \& Hirsch, P. (2000). Staleya guttiformis gen. nov., sp. nov. and Sulfitobacter brevis sp. nov., $\alpha-3$-Proteobacteria from hypersaline, heliothermal and meromictic antarctic Ekho Lake. Int J Syst Evol Microbiol 50, 303-313.

Mesbah, M., Premachandran, U. \& Whitman, W. B. (1989). Precise measurement of the $\mathrm{G}+\mathrm{C}$ content of deoxyribonucleic acid by high-performance liquid chromatography. Int J Syst Bacteriol 39, 159-167.

Mukhopadhyaya, P. N., Deb, C., Lahiri, C. \& Roy, P. (2000). A soxA gene, encoding a diheme cytochrome $c$, and a sox locus, essential for sulfur oxidation in a new sulfur lithotrophic bacterium. J Bacteriol 182, 4278-4287.

Rogel, M. A., Hernández-Lucas, I., Kuykendall, D. L., Balkwill, D. L. \& Martinez-Romero, E. (2001). Nitrogen-fixing nodules with Ensifer adhaerens harboring Rhizobium tropici symbiotic plasmids. Appl Environ Microbiol 67, 3264-3268.

Rother, D., Henrich, H.-J., Quentmeier, A., Bardischewsky, F. \& Friedrich, C. G. (2001). Novel genes of the sox gene cluster, mutagenesis of the flavoprotein SoxF, and evidence for a general sulfur-oxidizing system in Paracoccus pantotrophus GB17. J Bacteriol 183, 4499-4508.

Saitou, N. \& Nei, M. (1987). The neighbor-joining method: a new method for reconstructing phylogenetic trees. Mol Biol Evol 4, 406-425.

Segovia, L., Piñero, D., Palacios, R. \& Martinez-Romero, E. (1991). Genetic structure of a soil population of nonsymbiotic Rhizobium leguminosarum. Appl Environ Microbiol 57, 426-433.

Sneath, P. H. A. \& Sokal, R. R. (1973). Numerical Taxonomy. San Francisco: W. H. Freeman.

Sullivan, J. T., Eardly, B. D., van Berkum, P. \& Ronson, C. W. (1996). Four unnamed species of nonsymbiotic rhizobia isolated from the rhizosphere of Lotus corniculatus. Appl Environ Microbiol 62, 2818-2825.

Tighe, S. W., de Lajudie, P., Dipietro, K., Lindström, K., Nick, G. \& Jarvis, B. D. W. (2000). Analysis of cellular fatty acids and phenotypic relationships of Agrobacterium, Bradyrhizobium, Mesorhizobium, Rhizobium and Sinorhizobium species using the Sherlock Microbial Identification System. Int J Syst Evol Microbiol 50, 787-801.

Velázquez, E., Igual, J. M., Willems, A. \& 9 other authors (2001). Mesorhizobium chacoense sp. nov., a novel species that nodulates Prosopis alba in the Chaco Arido region (Argentina). Int J Syst Evol Microbiol 51, 1011-1021.

Vinuesa, P., Silva, C., Lorite, M. J., Izaguirre-Mayoral, M. L., Bedmar, E. J. \& Martínez-Romero, E. (2005). Molecular systematics of rhizobia based on maximum likelihood and Bayesian phylogenies inferred from $r r s, a t p D, r e c A$ and nifH sequences, and their use in the classification of Sesbania microsymbionts from Venezuelan wetlands. Syst Appl Microbiol 28, 702-716.

Vishniac, W. \& Santer, M. (1957). The thiobacilli. Bacteriol Rev 21, 195-213.

Wang, E. T., van Berkum, P., Sui, X. H., Beyene, D., Chen, W. X. \& Martínez-Romero, E. (1999). Diversity of rhizobia associated with 
Amorpha fruticosa isolated from Chinese soils and description of Mesorhizobium amorphae sp. nov. Int J Syst Bacteriol 49, 51-65.

Wang, E. T., Kan, F. L., Tan, Z. Y., Toledo, I., Chen, W. X. \& MartínezRomero, E. (2003). Diverse Mesorhizobium plurifarium populations native to Mexican soils. Arch Microbiol 180, 444-454.

Weir, B. S., Turner, S. J., Silvester, W. B., Park, D.-C. \& Young,

J. M. (2004). Unexpectedly diverse Mesorhizobium strains and
Rhizobium leguminosarum nodulate native legume genera of New Zealand, while introduced legume weeds are nodulated by Bradyrhizobium species. Appl Environ Microbiol 70, 59805987.

Young, J. P. W. (1998). Bacterial evolution and the nature of species. In Advances in Molecular Ecology, pp. 119-131. Edited by G. R. Carvalho. Amsterdam: IOS Press. 